\title{
Hypoglycemic activity of Capparis ovata desf. var. palaestina zoh. methanol extract
}

\author{
Mehmet Evren Okur ${ }^{1 *}$, Hanefi Özbek², Derya Çiçek Polat ${ }^{3}$, Sezen Yılmaz $^{4}$, Rana Arslan$^{1}$
}

${ }^{1}$ Department of Pharmacology, Faculty of Pharmacy, Anadolu University, Eskisehir, Turkey, ${ }^{2}$ Department of Pharmacology, School of Medicine, Istanbul Medipol University, Istanbul, Turkey, ${ }^{3}$ Department of Pharmaceutical Botany, Faculty of Pharmacy, Ankara University, Ankara, Turkey, ${ }^{4}$ Department of Toxicology, Faculty of Pharmacy, Ankara University, Ankara, Turkey

\begin{abstract}
Caper (Capparis ovata Desf. and Capparis spinosa L.) is naturally widespread in Turkey. Traditionally, buds, fruits, seeds and roots of this plant are used as tonic, diuretic, anti-rheumatic, expectorant, antidiabetic, and antifungal. The aim of this study is to evaluate potential hypoglycemic effect of $C$. ovata var. palaestina extracts in alloxan-induced diabetic mice. For this purpose; diabetic mice were administered with 100,300, $500 \mathrm{mg} / \mathrm{kg}$ (i.p.) doses of methanol extract of bud and fruit. Blood glucose levels were screened 60, 120, 240 and $360 \mathrm{~min}$. after treatment. Furthermore, high resolution mass spectrometry (HRMS) analysis, ABTS and $D P P H$ free radical scavenging activity test, and phenolic and flavonoid compounds analysis of extracts were carried out. The data obtained from in vivo study revealed that fruit-methanol $500 \mathrm{mg} / \mathrm{kg}$ (FM3), bud-methanol $300 \mathrm{mg} / \mathrm{kg}$ (BM2), bud-methanol $500 \mathrm{mg} / \mathrm{kg}$ (BM3) extracts showed significant hypoglycemic activity. All extracts indicated significant antioxidant activity, however bud-methanol (BM) extract demonstrated the most potent antioxidant activity. Moreover high levels of phenolic substances and flavonoids were involved in all extracts, but the highest levels were found in FM extract. HRMS study showed that rutin, quercetin 3-O-glucoside (isoquercitrin) and stachydrine substances had seen in BM extract. The results of this study showed that the C. ovata var. palaestina extracts which, indicate hypoglycemic, antioxidant activities, might provide additional support in diabetes.
\end{abstract}

Keywords: C. ovata var. palaestina/extract. C. ovata var. palaestina/hypoglycemic effect/antioxidant effects. Diabetes mellitus. Mice.

\section{INTRODUCTION}

Diabetes mellitus (DM) is a group of metabolic diseases which characterized by high blood glucose (hyperglycemia) resulting from either defects in insulin secretion, or insufficient insulin action, or both. The chronic hyperglycemia can induce failure or dysfunction of diffirent organs, especially the eyes, kidneys, nerves, heart, and blood vessels (ADA, 2010). According to the World Health Organization (WHO) report, prevalence of DM is globally about 171 million and predicted to reach 366 million by the end of 2030 (Manaer et al., 2015). DM is exactly recognized as a global public health problem,

\footnotetext{
*Correspondence: M. E. Okur. Department of Pharmacology, Faculty of Pharmacy, Anadolu University, Tepebasi, Eskisehir, Turkey. Tel.: +90 555822 28 40. E-mail address: evrenokurecz@gmail.com
}

considered the most challenging metabolic endemic of the 21st century (Okur et al., 2017).

Type 1 diabetes is a chronic illness characterized by insulin deficiency. Therefore different types of insulin such as fast acting insulins involving lispro, aspart, glulisine, and long acting insulins possessing detemir, glargine, degludec and finally the intermediate acting insulins are used for treatment of type 1 diabetes. Metformin is the main drug for the treatment of type 2 diabetes. Depending on the HbA1c values, different types of drugs such as dipeptidyl peptidase-4 (DPP-4) inhibitors, thiazolidinediones, sulfonylureas, sodium glucose cotransporter (SGLT2) inhibitors, glucagon like peptide-1 (GLP-1) receptor agonists and insulin might be added at different levels to dual or triple therapy of treatment of type 2 diabetes (ADA, 2017).

Despite the currently available conventional drugs the treatment of diabetes has been a difficult task. This is 
due to the unwanted side effects associated with the use of the conventional drugs, which include hypoglycemia, weight gain, hypersensitivity, gastrointestinal discomfort, nausea, liver and heart failure, and diarrhea (Mohammed et al., 2016). Apart from conventional antidiabetic therapy, several studies have shown that diet, use of medicinal plants, complementary and alternative medicine therapies have beneficial effects and improve glucose homeostasis in diabetic patients (Fallah Huseini et al., 2013). It is a necessity to research for effective, economic, accessible, and safe drug candidates for treatment of DM. Thus researching the effectiveness of plants could be a good option (Sheikh et al., 2016).

Capparis species (Capparaceae), also known as Caper is represented by about 250 species as well as has wide natural distribution in many different regions worldwide. Caper has been used traditionally for several therapeutic effects since ancient times such as diuretic, laxative, analgesic (Arslan, Bektas, 2010; Tlili et al., 2011). In addition, antidiabetic activities of several species such as C. decidua (Yadav et al., 1997), C. spinosa (Kazemian et al., 2015), and C. moonii (Kanaujia et al., 2010) have been shown. The biological activities that Caper species have shown are due to their bioactive contents such as glucosinolates, alkaloids, flavonoids and phenolic acids (Arslan, Bektas, Ozturk, 2010; Gull et al., 2015). In Turkey, two species (C. spinosa and C. ovata) of Capparis L. are grown and each species is represented by three varieties. These varieties are: $C$. spinosa $\mathrm{L}$. var. spinosa L., C. spinosa L. var. inermis Turra., C. spinosa L. var. aegyptia (Lam) Boiss, and; C. ovata Desf. var. palaestina Zoh., C. ovata Desf. var. herbacea (Wild) Zoh., and C. ovata Desf. var. canescens (Coss.) Heywood (Özbek, Kara, 2013) .

The aim of the present study is to evaluate hypoglycemic and antioxidant activities of Capparis ovata Desf. var. palaestina Zoh., which has not reported its biological effects on diabetes before. Along with in vivo hypoglycemic activity test of $C$. ovata var. palaestina methanol extracts, $D P P H$ and $A B T S^{\circ+}$ free radical scavenging activity studies were examined. Therewithal, in order to determine phytochemical constituents, phenolic and flavonoid substances were investigated and also extracts were quantitatively analyzed by using HRMS.

\section{MATERIAL AND METHODS}

\section{Plant material}

In the present study, buds and fruits of $C$. ovata var. palaestina (Capparidaceae), collected from Batman,
Turkey. Voucher samples were deposited in Herbarium of Ankara University Faculty of Pharmacy (No: *AEF 26797, *AEF 26798). * (AEF:Ankara Üniversitesi Eczacilik Fakültesi Herbaryumu)

\section{Laboratory animals}

BALB-c mice (25-28 g) were procured from İstanbul Medipol University, MEDITAM, İstanbul, Turkey. The mice were hosted in regular cages with food and water ad libitum, at room temperature $\left(20 \pm 2{ }^{\circ} \mathrm{C}\right)$ with artificial light from 7.00 am to $7.00 \mathrm{pm}$. Prior to perform in vivo experiments, ethical clearance approval was obtained from the Institutional Animals Ethical Committee (Approval No.-38828770-604.01.01-E.5775). All procedures involving animals were conducted in accordance with the National Institutes of Health (NIH) Guide for the Care and Use of Laboratory Animals (NIH publication no. 85-23, revised in 1985).

\section{Preparation of Capparis ovata var. palaestina extracts}

Buds and fruits of C. ovata var. palaestina were air-dried, then powdered. For methanolic extracts, each samples were extracted with methanol for $24 \mathrm{~h}$. After filtered, the extracts were concentrated in vacuo at $40{ }^{\circ} \mathrm{C}$. The dry residue was stored at $4{ }^{\circ} \mathrm{C}$. The extract yields of fruits were calculated as $10.21 \%(\mathrm{w} / \mathrm{w})$ while as the extract yields of buds were calculated as $12.26 \%(\mathrm{w} / \mathrm{w})$.

\section{Induction of diabetes and experimental design}

Mice were fasted for 18 hours and then diabetes was induced by intraperitoneal (i.p.) alloxan $(150 \mathrm{mg} / \mathrm{kg})$ injection to mice. This treatment was repeated 3 times with 48 hours intermission between per injections to induce diabetes in mice. 7 days after the final alloxan injection, mice with fasting blood glucose above $200 \mathrm{mg} / \mathrm{mL}$ were found to be sufficient for experimental diabetes and included in the study (Öntürk, Özbek, 2009).

\section{Animal grouping, dose determination and extract administration}

Animals were fasted eighteen hours before the experiments, but were allowed to water consumption. Mice were indiscriminately divided into fifteen groups each involving five animals: Group 1, diabetic mice received bud-methanol extract (100 $\mathrm{mg} / \mathrm{kg}$, i.p.)-(BM1); Group 2, diabetic mice received bud-methanol extract 
(300 mg/kg, i.p.)-(BM2); Group 3, diabetic mice received bud-methanol extract (500 mg/kg, i.p.)-(BM3); Group 4, diabetic mice received fruit-methanol extract $(100 \mathrm{mg} / \mathrm{kg}$, i.p.)-(FM1); Group 5, diabetic mice received fruitmethanol extract (300 mg/kg, i.p.)-(FM2); Group 6, diabetic mice received fruit-methanol extract $(500 \mathrm{mg} / \mathrm{kg}$, i.p.)-(FM3); Group 7, diabetic mice received glibenclamide (control - $3 \mathrm{mg} / \mathrm{kg}$, i.p.)-(GC); Group 8, diabetic mice received normal saline (control - $0,1 \mathrm{~mL} 0.9 \% \mathrm{NaCl}$, i.p.)(DC); Group 9, normoglycemic mice received normal saline (control - 0,1 mL 0.9\% NaCl, i.p.)-(NC). Blood samples were taken from the tail vein of mice at $0 \mathrm{~min}$ (before treatment) and 60, 120, 240 and 360 min after treatment. Blood glucose level was monitored by applying glucose oxidase peroxidase method (Abbott, United Kingdom).

\section{In vitro antioxidant activity}

\section{DPPH' Free radical scavenging activity}

The (2,2-diphenyl-1-picrylhydrazyl) $D P P H$ free radical scavenging activity of extracts were detected by their capacity of bleaching the stable radical DPPH (Blois, 1958). The reaction solution consisted of a mixture of $100 \mathrm{M}$ DPPH in methanol with different concentrations of the extract. After $0.5 \mathrm{~h}$ at room temperature, absorbance was measured at $517 \mathrm{~nm}$, and the free radical scavenging activity was detected as the percentage of the radical reduction. Each test was repeated three times. $\mathrm{IC}_{50}$ values were detected from a calibration graph for each prepared extracts. As reference compound, butylated hydroxytoluene (BHT) was used.

Percentage of inhibition $=\left[\left(\right.\right.$ Optical density ${ }_{\text {control }}-$ Optical density test sapmLe $)$ / Optical density control $\left.\left._{\text {con }}\right)\right]$ x 100

\section{$A B T S^{*}$ Free radical scavenging activity}

Antioxidant activity of the extracts was determined by [2,2'-azino-bis(3-ethylbenzthiazoline-6-sulphonic acid)] $A B T S$ radical cation decolorization test ( $\mathrm{Re}$ et al., 1999). The ABTS radical cation was produced by mixing ABTS stock solution ( $7 \mathrm{mM}$ in water) with $2.45 \mathrm{mM}$ potassium persulfate. Subsequently, this mixed solution was kept for 12-16 h. at room temperature in a dark room before usage. The ABTS solution was diluted with ethanol to regulate an absorbance value of $0.70 \pm 0.02$ at $734 \mathrm{~nm}$. The sample was diluted 100-fold with the ABTS solution to a total volume of $1 \mathrm{~mL}$. The absorbance of the solution was detected spectrophotometrically at $734 \mathrm{~nm} 6$ min after preparation and the percentage of inhibition was calculated. Each test was performed at least in triplicates. Controls without $A B T S$ were used to allow for any absorbance of the extracts themselves and $990 \mu \mathrm{L}$ of ethanol was added to these control samples instead. Because of self-degradation of the radical, $A B T S$ stock solutions were freshly prepared in every 5 days. The test was primary performed on Trolox (used as standard) which is a water-soluble $\alpha$-tocopherol analogue. The results were expressed as $\mathrm{IC}_{50}$.

Percentage of inhibition $=\left[\left(\right.\right.$ Optical density ${ }_{\text {control }}-$ Optical density test sapmLe $_{\text {( }}$ / Optical density control $_{\text {Co }}$ x 100

\section{Analysis of phenolic and flavonoid compounds}

\section{Determination of total phenolic contents of the extracts}

The amount of phenolic content in the extracts were measured according to Folin-Ciocalteu technique. $5 \mathrm{~mL}$ of each extract, $0.25 \mathrm{~mL} \mathrm{10 \%} \mathrm{Folin-Ciocalteau's} \mathrm{reagent}$ $(\mathrm{v} / \mathrm{v})$ and $0.2 \mathrm{~mL} \mathrm{7.5 \%} \mathrm{Na}_{2} \mathrm{CO}_{3}(\mathrm{w} / \mathrm{v})$ were mixed. Then sample was incubated at $45^{\circ} \mathrm{C}$ for $15 \mathrm{~min}$. The absorbance of each sample was determined at $765 \mathrm{~nm}$. The total phenolic content was measured from a calibration curve $\left(R^{2}=0.9811\right)$ and final values were expressed as mg gallic acid equal per $100 \mathrm{~g}$ extract. For all samples, each test was repeated thrice (Heydari, Saltan, Acikara, 2015).

\section{Determination of total flavonoid contents of the extracts}

The amount of flavonoid content in the extracts were determined by the aluminium chloride colorimetric assay. In brief, $50 \mu \mathrm{L}$ of extract was completed to $1 \mathrm{~mL}$ with methanol, then $4 \mathrm{~mL}$ of distilled water and $0.3 \mathrm{~mL}$ $5 \% \mathrm{NaNO}_{2}$ solution were added and mixed. Followed by 5 min incubation, $0.3 \mathrm{~mL} 10 \% \mathrm{AlCl}_{3}$ solution was added and the mixture was allowed to wait for $6 \mathrm{~min}$. Then, $2 \mathrm{~mL} 1 \mathrm{~mol} / \mathrm{L} \mathrm{NaOH}$ solution were added. Finally, the mixture was completed to $10 \mathrm{~mL}$ with double-distilled water and was allowed to wait for $15 \mathrm{~min}$. The absorbance of each sample was determined at $510 \mathrm{~nm}$. The total flavonoid content was measured from a calibration curve $\left(\mathrm{R}^{2}=0.9978\right)$ and final values were expressed as $\mathrm{mg}$ quercetin equivalent per $100 \mathrm{~g}$ extract. For all sample, each test was repeated thrice (Chia-Chi Chang et al., 2002).

\section{High-resolution mass spectrometry (HRMS)}

HRMS analysis were performed on a hybrid IT-TOF mass spectrometer with ESI interface (both positive and negative mode) (Shimadzu, Kyoto, Japan). The positive ESI conditions were as follows: high voltage probe, $-3.5 \mathrm{kV}$ (for negative ESI, it was $3.5 \mathrm{kV}$ ); nebulizing gas flow, $1.5 \mathrm{~L} / \mathrm{min}$; CDL temperature, $200{ }^{\circ} \mathrm{C}$; heat block temperature, $200{ }^{\circ} \mathrm{C}$; drying gas pressure, $200 \mathrm{KPa}$. 
CID parameters were settled 50\% for CID energy, 50\% for collision gas parameter and Argon gas was used for CID. Detector voltage of TOF was $1.6 \mathrm{kV}$. A solution of trifluoroacetic acid (TFA) and sodium hydrate was consumed as the standard sample for postrun calibration. LC part was consisted of two LC-20AD dual pump, DGU-20A3R degasser unit, CTO-10ASvp column oven, SIL-20AC autosampler and SPD-M20A PDA detector. In the analysis, inertsil ODS-3 (150 $\mathrm{mm} \times 1.5 \mathrm{~mm}, 5 \mathrm{um})$, were used as stationary phase and the mix of Water/ Acetonitrile (0.1\% Formic acid) was used gradually as mobile phase. Data were processed by using LCMS solution software (v. 3.80). In high resolution mass spectrometer analysis, extracts were dissolved in methanol and injected to system as $1 \mu \mathrm{L}$ injection volume.

\section{Statistical analysis}

In vivo test results are presented as mean \pm standard error of the mean (SEM). Statistical analysis of in vivo test results was performed using one-way ANOVA followed by Dunnett's post-tests using the Graphpad ver. 5 software. Antioxidant test results are presented as mean \pm standard deviation (SD). Statistical analysis of antioxidant test results was completed using one-way ANOVA with the SPSS 23.0 software. A difference in the mean values of $P<0.05$ was considered to be statistically significant.

\section{RESULTS AND DISCUSSION}

It has been stated that different Capparis species such as, C. aphylla (Dangi, Mishra, 2010), C. mooni (Kanaujia et al., 2010), C. zeylanica (Deepa, Jasmine, Agastian, 2013), C. decidua (Yadav, Sarkar, Bhatnagar, 1997) and C. spinosa (Mishra et al., 2012) indicate effectiveness on diabetes. Along with this, the hypoglycemic effects of $C$. ovata varieties has not been researched before. According to previous studies which were performed with $C$. ovata varieties; It was administered at a dose range of 100-2000 $\mathrm{mg} / \mathrm{kg}$ and no toxic effect was observed in mice. However, it has been indicated that methanol extracts of fruit and bud (100, 200, $300 \mathrm{mg} / \mathrm{kg}$-i.p.) have antithrombotic and anti-inflammatory effects and methanol extract of fruit (50, $100,200 \mathrm{mg} / \mathrm{kg}$-i.p.) have antinociceptive effect (Arslan, Bektas, Ozturk, 2010; Bektas et al., 2012).

\section{Acute effects of $C$. ovata var. palaestina extracts on blood glucose levels in diabetic mice}

Alloxan destroy pancreatic $\beta$-cells to induce hyperglycemia. Its notified that range of $140-180 \mathrm{mg} / \mathrm{kg}$ dose range of alloxan may be efficient for this purpose in mice (Eddouks, Lemhadri, Michel, 2005), besides this $150 \mathrm{mg} / \mathrm{kg}$ alloxan might cause adequate and nonexcessive diabetes (Öntürk, Özbek, 2009). Therefore the dose of alloxan was selected $150 \mathrm{mg} / \mathrm{kg}$ (i.p.).

Fasting blood glucose (FBG) levels after single i.p. application of methanol extracts of $C$. ovata var. palaestina's buds and fruits are shown in Table I. Accordingly, depending on the mean results of FBG in diabetic mice at $0,60,120,240$ and 360 minutes; BM1, BM2, BM3, FM3, GC treatments showed continuous reduction of FBG with time when compared to initial time (0 min), whereas FM1, FM2 and DC treatments showed an increase of FBG at 60 min then showed continuous reduction. Additionally, normoglycemic control (NC) group mostly showed continuous reduction of FBG with time when compared to initial time $(0 \mathrm{~min})$. It was observed that fasting blood glucose levels were decreasing in a dose dependent manner with both fruit and bud extracts. Furthermore, the highest reduction rate in the extract treatments was seen in the BM3 group. Treatments that cause fasting blood glucose to decrease below $200 \mathrm{mg} / \mathrm{dL}$ in diabetic mice are GC (240-360 min) and BM3 (360 min) (Table I).

Figure 1 depicted that the hypoglycemic effect of C. ovata var. palaestina's fruit and bud methanol extracts on the fasting blood glucose in normal and diabetic mice. The administration of the glibenclamide ( $3 \mathrm{mg} / \mathrm{kg}$, i.p)(GC) significantly decreased blood glucose at $60 \mathrm{~min}$ $\left({ }^{* *} P<0.01\right), 120 \min \left({ }^{* *} P<0.01\right), 240 \min \left({ }^{* * *} P<0.001\right)$ and $360 \mathrm{~min}\left({ }^{* * *} P<0.001\right)$ when compared with diabetic control (DC) group in diabetic mice. The administration of the fruit extracts; FM3 $(500 \mathrm{mg} / \mathrm{kg}$ ) group at $360 \mathrm{~min}$ $\left({ }^{*} P<0.05\right)$ significantly decreased blood glucose when compared with DC group in diabetic mice. However no significant difference in blood glucose levels was observed with FM1 (100 mg/kg) and FM2 (300 mg/kg) groups. The administration of the bud extracts; BM1 $(100 \mathrm{mg} / \mathrm{kg})$ and BM2 $(300 \mathrm{mg} / \mathrm{kg})$ groups did not show any significant change on blood glucose level. On the other hand, BM3 $(500 \mathrm{mg} / \mathrm{kg})$ at $240 \mathrm{~min}\left({ }^{*} P<0.05\right)$, and $360 \mathrm{~min}\left({ }^{* * *} P<0.001\right)$, significantly decreased blood glucose when compared with DC group in diabetic mice.

The mechanism of potential hypoglycemic effect which is exhibited by C. ovata var. palaestina's extracts, might be the result of potentiation of the insulin secration or effect. It is also thought one of the mechanisms of hypoglycemia induced by $C$. ovata var. palaestina extracts is an pancreatic mechanism (Almeida et al., 2006). Moreover, several compounds such as saccharides, glycosides, alkaloids, terpenoids, volatile oils, fatty acids, 
Hypoglycemic activity of Capparis ovata desf. var. palaestina zoh. methanol extract

TABLE I - Acute effects of methanol extracts of C. ovata var. palaestina bud and fruit on fasting blood glucose levels (mg/dL) in diabetic mice. Values are presented as the mean \pm SEM

\begin{tabular}{lccccc}
\hline Group & 0 min & 60 $\mathbf{~ m i n}$ & $\mathbf{1 2 0}$ min & $\mathbf{2 4 0}$ min & 360 min \\
\hline BM1 & $333.4 \pm 56.196$ & $321.2 \pm 71.810$ & $287.8 \pm 75.303$ & $270.2 \pm 73.393$ & $244.8 \pm 75.813$ \\
BM2 & $338.2 \pm 34.420$ & $337.4 \pm 25.295$ & $294.4 \pm 36.215$ & $271.8 \pm 41.693$ & $215.8 \pm 64.366$ \\
BM3 & $325.2 \pm 35.012$ & $313.8 \pm 37.747$ & $309.2 \pm 40.940$ & $226.6 \pm 44.536$ & $147.4 \pm 32.873$ \\
FM1 & $311 \pm 27.969$ & $340.6 \pm 29.696$ & $325.2 \pm 16.035$ & $304.4 \pm 20.934$ & $234.6 \pm 40.708$ \\
FM2 & $372.8 \pm 15.951$ & $374.2 \pm 18.529$ & $373.4 \pm 20.903$ & $299.6 \pm 27.312$ & $258.4 \pm 38.347$ \\
FM3 & $378.4 \pm 36.104$ & $360.4 \pm 32.103$ & $336.6 \pm 39.618$ & $280.2 \pm 34.245$ & $225.4 \pm 38.405$ \\
GC & $332.8 \pm 52.336$ & $232.2 \pm 47.276$ & $210.6 \pm 38.771$ & $139.6 \pm 12.548$ & $138.4 \pm 12.548$ \\
DC & $402.8 \pm 48.89$ & $454 \pm 57.31$ & $443.2 \pm 66.58$ & $410.2 \pm 66.34$ & $390.4 \pm 69.5$ \\
NC & $149.8 \pm 11.62$ & $140.6 \pm 6.249$ & $135.6 \pm 6.265$ & $144.4 \pm 8.298$ & $115.8 \pm 9.702$ \\
\hline
\end{tabular}

steroids, several minerals might effect glucose or insulin metabolism (Fallah Huseini et al., 2013).

\section{In vitro antioxidant activity}

Diabetes is an oxidative stress based disorder which is caused by an imbalance between the cellular production of reactive oxygen species and the deactivating these products by natural antioxidant mechanisms of body (Gothai et al., 2016). Oxidative stress has a critical role in systemic inflammation, endothelial dysfunction, impaired secretion of pancreatic $\beta$-cells and impaired glucose utilization in peripheral tissues (Zatalia, Sanusi, 2013). Free radical formation in diabetes by non-enzymatic glycation of proteins, glucose oxidation and increased lipid peroxidation leads to damage of enzymes, cellular machinery and also increased insulin resistance due to oxidative stress (Ullah, Khan, Khan, 2016). Therefore, plants which have antioxidant activity, can enhance $\beta$-cell function and the insulin secretion from the islets of Langerhans (Jerine Peter, Sabina, 2016). Hereby, antioxidants might have an important role in the relieving of DM (Jayasri et al., 2008). Several studies have exhibited the antioxidant activity of $C$. ovata L. (Ünver et al., 2009), C. ovata Desf. var. canescens (El-Ghorab, Shibamoto, Özcan, 2007) and C. ovata subsp. ovata (Aichi-Yousfi et al., 2016).

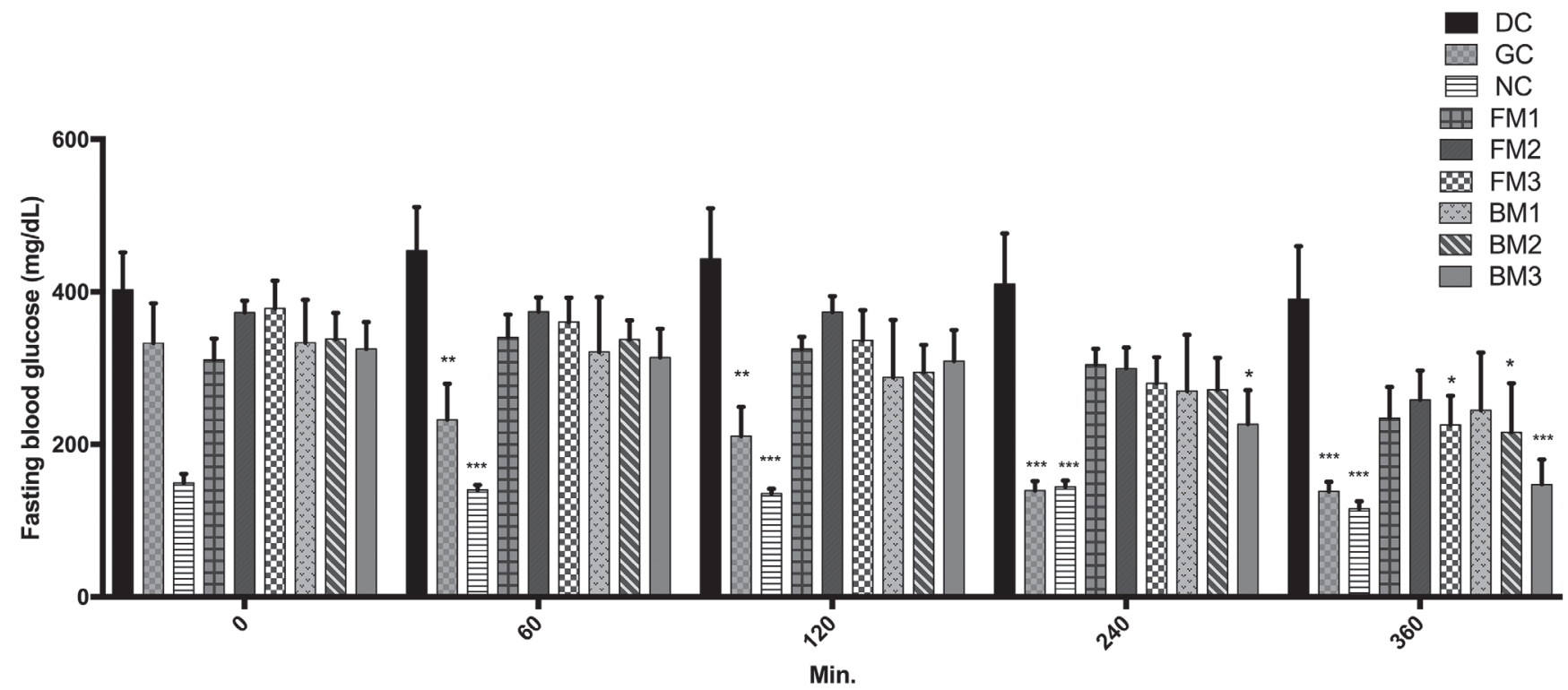

FIGURE 1 - The hypoglycemic effect of fruits-buds of C. ovata var. palaestina's methanol extracts. Values are presented as the mean \pm SEM. DC: diabetic control, GC: glibenclamide-control, NC: normoglycemic-control, FM1: fruit methanol $100 \mathrm{mg} / \mathrm{kg}, \mathrm{FM}$ : fruit methanol $300 \mathrm{mg} / \mathrm{kg}$, FM3: fruit methanol $500 \mathrm{mg} / \mathrm{kg}$, BM1: bud methanol $100 \mathrm{mg} / \mathrm{kg}$, BM2: bud methanol $300 \mathrm{mg} / \mathrm{kg}$, BM3: bud methanol $500 \mathrm{mg} / \mathrm{kg} .{ }^{*} P<0.05,{ }^{* *} P<0.01,{ }^{* * *} P<0.001$; significant difference from diabetic-control (DC) group. 
In general, it is an acceptable application to test antioxidant activities of samples with two different analyzing methods (El-Ghorab, Shibamoto, Özcan, 2007). In our study, antioxidant activity of extracts were analyzed by $D P P H$ and $A B T S$ free radical scavenging activity test. $D P P H$ and $A B T S$ free radical scavenging test values of $C$. ovata var. palaestina extracts were presented in Table II. According to the $D P P H$ test results, BM has shown the highest activity $(0.096 \pm 0.007 \mathrm{mg} /$ $\mathrm{mL}$ ), furthermore both extracts also had significant free radical scavenging activities as compared to butylated hydroxytoluene (BHT) $(P<0.05)$. On the other hand, according to other $(A B T S)$ test results, $\mathrm{BM}$ was characterized by the highest antioxidant activity $(0.063 \pm 0.009 \mathrm{mg} / \mathrm{mL})$ as well as both extracts have significant free radical scavenging activities as compared to Trolox $(P<0.05)$. Both test $(A B T S$ and $D P P H)$ results were indicated the strong resemblance. $\mathrm{BM}$ have a higher free radical scavenging activities than FM. Antioxidant activity that depicted in the extracts, might contribute to in vivo antidiabetic effect.

\section{Analysis of phenolic and flavonoid compounds}

Plant originated antioxidants are grouped as vitamins, phenolic compounds and flavonoids (El-Ghorab, Shibamoto, Özcan, 2007). It is indicated that phenolic acids and flavonoids have effectiveness in treating diabetes and its complications due to potent antioxidant activity (Gu et al., 2015). Capparis species have rich alkaloids, lipids, polyphenols, flavonoids, and glucosinolates (Nazıroğlu et al., 2011)

In this study phenolic compounds in C. ovata var. palaestina extracts were measured by using FolinCiocalteu reagent. Total phenolic compound of two extract of C. ovata var. palaestina were screened. The lowest total phenolic value was $603.25 \pm 4.24 \mathrm{mgGAE} / 100 \mathrm{~g}$ from bud extract and the highest total phenolic value was $1017.42 \pm 44.18 \mathrm{mgGAE} / 100 \mathrm{~g}$ from fruit extract. Various factors such as; solvent, geographic origin, stresses of environment were linked to these content variations (Aichi-Yousfi et al., 2016).

Flavonoids are one of the most common group of plant phenolics are flavonoids which could be graded such as flavones, flavonols, flavanones, flavonols, anthocyanins and isoflavonoids. (Guimarães et al., 2013). It is recognized that flavonoids which display potent antioxidant activity, can prop the regeneration of $\beta$-cells. (Liu et al., 2016). Total flavonoid compound of two extract of C. ovata var. palaestina were screened. The lowest total flavonoid value was $1940 \pm 4.24 \mathrm{mgQE} / 100 \mathrm{~g}$ from bud extract and the highest was $2990 \pm 21.21 \mathrm{mgQE} / 100 \mathrm{~g}$ from fruit extract. Tlili et al. stated that antioxidant activities of $C$. spinosa are related to the high level of phenolic compounds (Tlili et al., 2011).

According to obtained results, it was seen that fruit extract contains 1.5 times more flavonoid and phenolic substance than bud extract. BM extract which was indicated in vivo hypoglycemic activity, had the lowest phenolic/flavonoid content and showed potent antioxidant effect. Although the FM extract had more phenolic and flavonoid substances, it exhibited lower antioxidant activity and weaker hypoglycemic activity.

\section{High-resolution mass spectrometry (HRMS)}

Results both positive and negative mode were evaluated by literature knowledge and database on drugbank.ca. The identification of the compounds was carried out mainly by applying the mass fragmentation rules. A total of 3 components were detected in the BM extract using IT-TOF. Quercetin 3-O-glucoside, Rutin and Stachydrine were determined from the spectrum (Table III). The identities of 3 components were unambiguously determined by comparing their retention times and mass spectra with those of the pure compounds.

Rutin is a phenolic compound which has antioxidant, antidiabetic and anti-inflammatory activities. Rutin which has several effect on diabetes (Niture, Ansari, Naik, 2014), was investigated in C. ovata var. palaestina extracts by

TABLE II - Antioxidant activity results of C. ovata var. palaestina extracts

\begin{tabular}{lcc}
\hline Extract & $\boldsymbol{D P P H}-\mathrm{IC}_{50}(\mathbf{m g} / \mathbf{m L})$ & $\boldsymbol{A B T S}-\mathrm{IC}_{\mathbf{5 0}}(\mathbf{m g} / \mathbf{m L})$ \\
\hline Fruit-Methanol (FM) & $0.343^{*} \pm 0.033$ & $0.106^{*} \pm 0.001$ \\
Bud-Methanol (BM) & $0.096^{*} \pm 0.007$ & $0.063^{*} \pm 0.009$ \\
\hline Reference & $\boldsymbol{D P P H}-\mathrm{IC} \mathbf{C}_{\mathbf{5 0}}(\mathbf{m g} / \mathbf{m L})$ & $\boldsymbol{A B T S}-\mathrm{IC}_{50}(\mathbf{m g} / \mathbf{m L})$ \\
\hline Butylated hydroxytoluene (BHT) & $0.018^{*} \pm 0.001$ & - \\
Trolox & - & $0.015^{*} \pm 0.001$ \\
\hline
\end{tabular}

(*) Statistically significant as compared to control, $P<0.05$ (one-way ANOVA) 
Hypoglycemic activity of Capparis ovata desf. var. palaestina zoh. methanol extract

TABLE III - List of compounds determined by using IT-TOF

\begin{tabular}{lcccc}
\hline Compound & Molecular formula & Expected MW & Found MW & Retention time \\
\hline Stachydrine & $\mathrm{C}_{7} \mathrm{H}_{13} \mathrm{NO}_{2}$ & 144.1019 & 144.1020 & $2.2^{\prime}$ \\
Quercetin 3-O-glucoside(Isoquercitrin) & $\mathrm{C}_{21} \mathrm{H}_{20} \mathrm{O}_{12}$ & 465.1028 & 465.1015 & $11.9^{\prime}$ \\
Rutin & $\mathrm{C}_{27} \mathrm{H}_{30} \mathrm{O}_{16}$ & 611.1607 & 611.1613 & $11.9^{\prime}$ \\
\hline
\end{tabular}

HRMS method to determine possible hypoglycemic mechanism. It is previously reported that rutin was found in different parts of $C$. moonii and C. spinosa (Gull et al., 2015).

Isoquercitrin exhibits a broad range of positive biological effects both in vitro and in vivo, especially chemoprotective activities against oxidative stress, cancer, cardiovascular disorders, diabetes and allergic reactions. Panda et al. were evaluated the potential antidiabetic activity of isoquercitrin in rats. Isoquercitrin $(15 \mathrm{mg} / \mathrm{kg} /$ day, p.o. for 10 days) inhibited aloxan-induced hyperglycemia, hepatic and renal lipid peroxidation and the activity of hepatic glucose-6-phosphatase, while the activities of catalase and superoxide dismutase, and the content of glutathione were increased (Panda, Kar, 2007). In another study, isoquercitrin (single dose $100 \mathrm{mg} / \mathrm{kg}$, p.o.) also delayed the glycemic peak by $30 \mathrm{~min}$ in oral glucose tolerance tests and thus exhibited a timedependent anti-hyperglycemic activity (Paulo et al., 2008).

Stachydrine, as all betaines, is a quaternary ammonium compound. Betaines are ubiquitous in the vegetal world and tend to accumulate in the cytoplasm and intercellular fluids where they play an important role in protecting proteins, nucleic acids, and cell membranes against abiotic stress (Kavi Kishor et al., 2005; Street, Bolen, Rose, 2006). In a study, a high-glucose $(30 \mathrm{mM})$ cell culture model was used to simulate clinical hyperglycemia for the in vitro evaluation of the effect of stachydrine on high-glucose induced cytotoxicity. Servillo et al. clearly established that stachydrine, an abundant component of citrus juices, is able to prevent the highglucose cytotoxicity in endothelial cell by acting on the senescence and SIRT1 pathways (Servillo et al., 2013).

\section{CONCLUSION}

In conclusion, the present study can be considered as the first report focusing on hypoglycemic and antioxidant activity of C. ovata var. palaestina methanol extracts. The data obtained from in vivo study revealed that FM3, BM2, BM3 extracts showed significant acute hypoglycemic activity. All extracts indicated significant antioxidant activity, moreover BM extract demonstrated the most potent antioxidant activity. Furthermore, all extracts were involving high levels of phenolic substances and flavonoids, besides the highest levels were found in FM extracts. In the HRMS study, rutin, isoquercitrin and stachydrine substance was found in BM extract. The results of our study suggest that $C$. ovata var. palaestina is a valuable canditate for further research as alternative therapy for the management of DM and other associated complications.

\section{ACKNOWLEDGEMENT}

The authors are grateful to Serkan Levent from Anadolu University for the HRMS analysis.

\section{REFERENCES}

Aichi-Yousfi H, Meddeb E, Rouissi W, Hamrouni L, Rouz S, Rejeb MN, et al. Phenolic composition and antioxidant activity of aqueous and ethanolic leaf extracts of six Tunisian species of genus Capparis - Capparaceae. Ind Crops Prod. 2016;92:218-26.

Almeida ER, Guedes MC, Albuquerque JFC, Xavier H. Hypoglycemic effect of Bauhinia cheilandra in rats. Fitoterapia. 2006;77(4):276-8.

American Diabetes Association. ADA. Diagnosis and classification of diabetes mellitus. Diabetes Care. 2010;33(Suppl 1):62-9.

American Diabetes Association. ADA. Standards of medical care in diabetes. Diabetes Care. 2017;40(Suppl 1):57-74.

Arslan R, Bektas N. Antinociceptive effect of methanol extract of Capparis ovata in mice. Pharm Biol. 2010;48(10):1185-90.

Arslan R, Bektas N, Ozturk Y. Antinociceptive activity of methanol extract of fruits of Capparis ovata in mice. J Ethnopharmacol. 2010;131(1):28-32.

Bektas N, Arslan R, Goger F, Kirimer N, Ozturk Y. Investigation for anti-inflammatory and anti-thrombotic activities of methanol extract of Capparis ovata buds and fruits. J Ethnopharmacol. 2012;142(1):48-52. 
Blois M. Antioxidant determinations by the use of a stable free radical. Nature. 1958;181:1199-200.

Chia-Chi Chang, Yang M-H, Wen H-M, Chern J-C. Estimation of total flavonoid content in propolis by two complementary colorimetric methods. J Food Drug Anal. 2002;10(3):178-82.

Dangi KS, Mishra SN. Antihyperglycemic, antioxidant and hypolipidemic effect of Capparis aphylla stem extract in streptozotocin induced diabetic rats. Biol Med. 2010;2(4):35-44.

Deepa R, Jasmine DJ, Agastian P. In vitro alpha glucosidase mhibitory activity and GC-MS analysis of Capparis Zeylanica Linn R. Int J Pharm Sci Rev Res 2013;18:97-9.

Eddouks M, Lemhadri A, Michel JB. Hypolipidemic activity of aqueous extract of Capparis spinosa L. in normal and diabetic rats. J. Ethnopharmacol. 2005;98(3):345-350.

El-Ghorab A, Shibamoto T, Özcan MM. Chemical composition and antioxidant activities of buds and leaves of Capers (Capparis ovata Desf. var. canescens) cultivated in Turkey. J Essent Oil Res. 2007;19(1):72-7.

Fallah Huseini H, Hasani-Rnjbar S, Nayebi N, Heshmat R, Sigaroodi FK, Ahvazi M, et al. Capparis spinosa L. (Caper) fruit extract in treatment of type 2 diabetic patients: A randomized double-blind placebo-controlled clinical trial. Complement Ther Med. 2013;21(5):447-52.

Gothai S, Ganesan P, Park SY, Fakurazi S, Choi DK, Arulselvan P. Natural phyto-bioactive compounds for the treatment of type 2 diabetes: inflammation as a target. Nutrients. 2016;8(8):piiE461.

Gu JF, Zheng ZY, Yuan JR, Zhao BJ, Wang CF, Zhang L, et al. Comparison on hypoglycemic and antioxidant activities of the fresh and dried Portulaca oleracea L. in insulin-resistant HepG2 cells and streptozotocin-induced $\mathrm{C} 57 \mathrm{BL} / 6 \mathrm{~J}$ diabetic mice. J Ethnopharmacol. 2015;161:214-23.

Guimarães R, Barros L, Dueñas M, Carvalho AM, Queiroz MJRP, Santos-Buelga C, et al. Characterisation of phenolic compounds in wild fruits from Northeastern Portugal. Food Chem. 2013;141(4):3721-30.

Gull T, Anwar F, Sultana B, Alcayde MAC, Nouman W. Capparis species: A potential source of bioactives and high-value components: A review. Ind Crops Prod. 2015;67:81-96.
Heydari H, Saltan G, Acikara ÖB. Antioxidant activity of five Lathyrus L. Species growing in Turkey. Turkish J Pharm Sci. 2015;12:369-76.

Jayasri MA, Gunasekaran S, Radha A, Mathew TL. Anti-diabetic effect of Costus pictus leaves in normal and streptozotocininduced diabetic rats. Int J Diabetes Metab. 2008;16(3):117-22.

Jerine Peter S, Sabina EP. Global current trends in natural products for diabetes management: A review. Int J Pharm Pharm Sci. 2016;8(4):20-8.

Kanaujia A, Duggar R, Pannakal ST, Yadav SS, Katiyar CK, Bansal V, et al. Insulinomimetic activity of two new gallotannins from the fruits of Capparis moonii. Bioorganic Med Chem. 2010;18(11):3940-5.

Kavi Kishor PB, Sangam S, Amrutha RN, Sri Laxmi P, Naidu $\mathrm{KR}$, Rao KRSS, et al. Regulation of proline biosynthesis, degradation, uptake and transport in higher plants: Its implications in plant growth and abiotic stress tolerance. Curr Sci. 2005;88(3):424-38.

Kazemian M, Abad M, Haeri MR, Ebrahimi M, Heidari R. Antidiabetic effect of Capparis spinosa L. root extract in diabetic rats. Avicenna J Phytomedicine. 2015;5(4):325-32.

Liu Z, Zhai J, Han N, Yin J. Assessment of anti-diabetic activity of the aqueous extract of leaves of Astilboides tabularis. J Ethnopharmacol. 2016;194:635-41.

Manaer T, Yu L, Zhang Y, Xiao XJ, Nabi XH. Anti-diabetic effects of shubat in type 2 diabetic rats induced by combination of high-glucose-fat diet and low-dose streptozotocin. J Ethnopharmacol. 2015;169:269-74.

Mishra PR, Panda PK, Chowdary KA, Panigrahi S. Antidiabetic and antihypelipidaemic activity of Capparis spinosa extract. Int J Pharm Sci Rev Res. 2012;14(1):38-43.

Mohammed A, Koorbanally NA, Islam MS. Anti-diabetic effect of Xylopia aethiopica (Dunal) A. Rich. (Annonaceae) fruit acetone fraction in a type 2 diabetes model of rats. $\mathrm{J}$ Ethnopharmacol. 2016;180:131-9.

Nazıroğlu M, Gün H, Savaş Ş, Çelik Ö, Sözbir E, Özkaya MO, et al. Capparis ovata modulates ovariectomize induced-oxidative toxicity in brain, kidney and liver of aged mice. Cell Membr Free Radic Res. 2011;3(2):186-93. 
Niture NT, Ansari AA, Naik SR. Anti-hyperglycemic activity of Rutin in streptozotocin-induced diabetic rats: An effect mediated through cytokines, antioxidants and lipid biomarkers. Indian J Exp Biol. 2014;52(7):720-7.

Okur ME, Karantas ID, Siafaka PI. Diabetes Mellitus: a review on pathophysiology, current status of oral pathophysiology, current status of oral medications and future perspectives. Acta Pharm Sci. 2017;55(1):61.

Öntürk H, Özbek H. Evaluation of acute toxicity and hypoglycemic activity of trans-caryophyllene and eugenol on diabetic mice. Genel Tip Derg. 2009;19:17-23.

Özbek Ö, Kara A. Genetic variation in natural populations of Capparis from Turkey, as revealed by RAPD analysis. Plant Syst Evol. 2013;299:1911-33.

Panda S, Kar A. Antidiabetic and antioxidative effects of Annona squamosa leaves are possibly mediated through quercetin-3-Oglucoside. BioFactors. 2007;31(3-4):201-10.

Paulo A, Martins S, Branco P, Dias T, Borges C, Rodrigues AI, et al. The opposing effects of the flavonoids 1soquercitrin and sissotrin, isolated from Pterospartum tridentatum, on oral glucose tolerance in rats. Phyther Res. 2008;22(4):539-43.

Re R, Pellegrini N, Proteggente A, Pannala A, Yang M, RiceEvans C. Antioxidant activity applying an improved abts radical cation decolorization assay. Free Radic Biol Med. 1999;26(910):1231-7.
Servillo L, D’Onofrio N, Longobardi L, Sirangelo I, Giovane A, Cautela D, et al. Stachydrine ameliorates high-glucose induced endothelial cell senescence and SIRT1 downregulation. J Cell Biochem. 2013;114(11):2522-30.

Sheikh Y, Maibam BC, Talukdar NC, Deka DC, Borah JC. In vitro and in vivo anti-diabetic and hepatoprotective effects of edible pods of Parkia roxburghii and quantification of the active constituent by HPLC-PDA. J Ethnopharmacol. 2016;191:21-28.

Street TO, Bolen DW, Rose GD. A molecular mechanism for osmolyte-induced protein stability. Proc Natl Acad Sci. 2006;103(38):13997-4002.

Tlili N, Elfalleh W, Saadaoui E, Khaldi A, Triki S, Nasri N. The caper (Capparis L.): Ethnopharmacology, phytochemical and pharmacological properties. Fitoterapia. 2011;82(2):93-101.

Ullah A, Khan A, Khan I. Diabetes mellitus and oxidative stress - A concise review. Saudi Pharm J. 2016;24(5):547-53.

Ünver A, Arslan D, Özcan MM, Akbulut M. Phenolic content and antioxidant activity of some spices. World Appl Sci J. 2009;6(3):373-7.

Yadav P, Sarkar S, Bhatnagar D. Action of Capparis decidua against alloxan-induced oxidative stress and diabetes in rat tissues. Pharmacol Res. 1997;36(3):221-8.

Zatalia SR, Sanusi H. The role of antioxidants in the pathophysiology, complications, and management of diabetes mellitus. Acta Med Indones. 2013;45(2):141-7.

Received for publication on $12^{\text {th }}$ January 2018 Accepted for publication on $30^{\text {th }}$ January 2018 